\title{
Protein to energy ratios and cost, performance, and ammonia excretion in juvenile jundiá
}

\section{(Rhamdia quelen), South American catfish}

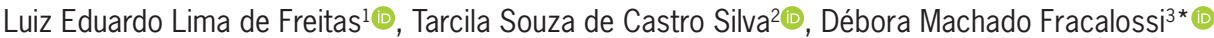

${ }^{1}$ Embrapa Pesca e Aquicultura, Prolongamento da Av. NS 10, Cruzamento com a Av. LO 18 Sentido Norte Loteamento Água Fria - 77008-900 - Palmas, T0 - Brasil.

2Embrapa Agropecuária Oeste, Rod. BR 163, km 253 6, s/n

- Zona Rural - 79804-970 - Dourados, MS - Brasil.

3Universidade Federal de Santa Catarina/CCA - Lab. de Nutrição de Espécies Aquícolas, Rod. Ademar Gonzaga, 1346 - 88034-001 - Florianópolis, SC - Brasil.

*Corresponding author <debora.fracalossi@ufsc.br>

Edited by: Melissa Izabel Hannas

Received September 15, 2020

Accepted November 04, 2020
ABSTRACT: The determination of nutritional requirements, based on diets administered in practice, considers physiological specificities and sustainability are essential to the development of suitable aquaculture technologies for novel fish species. The growth of jundiá (Rhamdia quelen Quoy and Gaimard) juveniles (31.54 $\pm 4.92 \mathrm{~g}$ ) fed five diets comprising increasing levels of digestible protein (DP: 24, 29, 34, 39, and $44 \%$ ) and digestible energy (DE: 12.13, 13.39, $13.81,14.64$, and $15.06 \mathrm{MJ} \mathrm{kg}^{-1}$ ) with DP:DE ratios: $20,22,25,27$, and $29 \mathrm{~g} \mathrm{MJ}^{-1}$, respectively, was evaluated. Each diet was fed to three groups of 25 fish for 75 days. Regression analysis showed that the different DP:DE ratios affected both growth and economic performance as well as excretion of total ammonia nitrogen. Fish fed diets with DP:DE ratios between 22 and $27 \mathrm{~g} \mathrm{MJ}^{-1}$ achieved a higher daily weight gain, superior apparent net protein utilization, feed conversion rates, and lower feed costs. For the economically viable and environmentally friendly farming of jundiá juveniles in the initial grow-out stage (30 to $80 \mathrm{~g}$ average weight), the best DP:DE ratio was $25 \mathrm{~g} \mathrm{MJ}^{-1} \mathrm{DP}: \mathrm{DE}$ (34.05\% DP and $\left.13.81 \mathrm{MJ} \mathrm{kg}^{-1} \mathrm{DE}\right)$.

Keywords: DP:DE, nutritional requirements, nitrogen excretion, practical diets

\section{Introduction}

Protein, a high-cost nutrient in aquafeeds, is a key determinant of fish growth and, consequently, of the profitability of aquaculture systems (Guy et al., 2018). The optimal level of this nutrient in feeds depends on several factors, including its amino acid profile, its digestibility (Glencross et al., 2007; Mo et al., 2019), and the associated availability of non-protein energy sources (Steffens, 1989; Mock et al., 2019; National Research Council, 2011). A delicate balance between the amounts of protein and energy (P:E) in aquafeeds is needed, considering that feed consumption is largely determined by the energy content provided in the diet (NRC, 2011).

Jundiá (Rhamdia quelen Quoy and Gaimard) is a fish species with husbandry potential found in subtropical regions such as southern Brazil, Argentina, and Uruguay. However, jundiá farming lacks species-specific technologies and the species is being commercially farmed using aquafeeds developed for other omnivorous fish, such as the Nile tilapia (Oreochromis niloticus L.). However, jundiá is not a typical omnivore, presenting a short intestine (Gominho-Rosa et al., 2015; Rodrigues et al., 2012) and having less ability to utilize dietary carbohydrates than Nile tilapia has (Moro et al., 2010; Oliveira Filho and Fracalossi, 2006; Rodrigues et al., 2012).

The protein requirements of jundiá have already been determined by dose-response studies; however, the values obtained differ considerably, ranging from 32 to $51 \%$ crude protein (Melo et al., 2006; Meyer and Fracalossi, 2004; Piedras et al., 2006; Reidel et al., 2010; Salhi et al., 2004; Signor et al., 2004; Tessaro et al., 2012). Among other reasons, this wide range is a factor in the determination of the protein requirement without a concomitant evaluation of the energy availability on dietary intake and protein utilization. In addition, the few studies that have considered the amount of energy in the diets used semi-purified ingredients (Meyer and Fracalossi, 2004; Salhi et al., 2004), which have limited application in the feed industry as a basis for formulating appropriate aquafeeds.

We aimed to analyze the performance of jundiá juveniles fed practical diets containing different digestible protein/digestible energy (DP:DE) ratios and whose formulation was based on the digestible nutrients needed by this species in the initial grow-out phase. In addition, we evaluated the cost of these diets in relation to weight gain and ammonia production by the fish with the aim of providing recommendations for the aquafeed industry and fish farmers.

\section{Materials and Methods}

This experiment was carried out from May to Aug 2015 in Florianópolis, Santa Catarina, Brazil $\left(27^{\circ} 43^{\prime} \mathrm{S}, 48^{\circ} 30^{\prime}\right.$ $\mathrm{W}^{\prime}$, altitude of $2.74 \mathrm{~m}$.).

\section{Experimental diets}

Five diets with increasing concentrations of DP: 24, 29, 34,39 , and $44 \%$ and DE: $12.13,13.39,13.81,14.64$, and $15.06 \mathrm{MJ} \mathrm{kg}^{-1}$, yielding DP:DE ratios of 20, 22, 25, 27, and $29 \mathrm{~g} \mathrm{MJ}^{-1}$, respectively, (Table 1) were formulated. The essential amino acid requirements reported for jundiá by Montes-Girao and Fracalossi (2006) were used in the formulation of these diets. The diet with DP:DE $20 \mathrm{~g} \mathrm{MJ}^{-1}$ was supplemented with synthetic amino acids to ensure the minimum dietary requirements of lysine and methionine. 
Table 1 - Formulation, cost and chemical composition (expressed on a dry matter basis) of five experimental diets fed to jundiá ( ) juveniles for 75 days.

\begin{tabular}{|c|c|c|c|c|c|}
\hline \multirow[t]{2}{*}{ Ingredient (\%) } & \multicolumn{5}{|c|}{$\begin{array}{c}\left.\text { Digestible protein (DP, } \mathrm{g} \mathrm{kg}^{-1}\right) \text { : Digestible energy (DE, MJ kg-1) } \\
\text { DP:DE ratio (g MJ-1) }\end{array}$} \\
\hline & 20 & 22 & 25 & 27 & 29 \\
\hline Soy protein concentrate ${ }^{1}$ & 10.00 & 16.50 & 22.10 & 27.60 & 33.20 \\
\hline Poultry by-product meal ${ }^{2}$ & 10.60 & 16.40 & 22.00 & 27.70 & 33.20 \\
\hline Salmon by-product meal ${ }^{3}$ & 18.00 & 18.00 & 18.00 & 18.00 & 18.00 \\
\hline Corn $^{4}$ & 58.90 & 46.40 & 35.40 & 23.90 & 13.40 \\
\hline Soybean oil & 0.90 & 1.70 & 1.50 & 1.80 & 1.20 \\
\hline Vitamin-mineral premix ${ }^{5}$ & 1.00 & 1.00 & 1.00 & 1.00 & 1.00 \\
\hline L-Lysine $^{6}$ & 0.30 & - & - & - & - \\
\hline DL-Methionine $^{6}$ & 0.40 & - & - & - & - \\
\hline \multicolumn{6}{|l|}{ Chemical composition (\%) } \\
\hline Dry matter & 89.00 & 89.57 & 89.75 & 89.91 & 90.25 \\
\hline Digestible protein & 24.10 & 28.96 & 34.05 & 39.00 & 43.87 \\
\hline Digestible energy (MJ kg-1) & 12.13 & 13.39 & 13.81 & 14.64 & 15.06 \\
\hline Crude fat & 7.45 & 7.75 & 8.15 & 8.71 & 8.67 \\
\hline Acid detergent fiber & 8.66 & 9.27 & 8.02 & 8.45 & 8.32 \\
\hline Ash & 10.53 & 7.24 & 9.21 & 11.80 & 11.72 \\
\hline Nitrogen-free extract ${ }^{7}$ & 32.73 & 28.53 & 22.43 & 12.56 & 7.49 \\
\hline Diet cost $\left(\mathrm{US} \$ \mathrm{~kg}^{-1}\right)^{8}$ & 2.76 & 2.44 & 2.67 & 2.93 & 3.22 \\
\hline
\end{tabular}

${ }^{1}$ Importação, Exportação e Indústria de Óleos (Paraná, Brazil); ${ }^{2}$ Doux-Frangosul (Rio Grande do Sul, Brazil); ${ }^{3}$ Tectron Nutrição Animal (Paraná, Brazil); ${ }^{4}$ Bunge Alimentos (São Paulo, Brazil); ${ }^{5}$ Raguife Indústria e Comércio (São Paulo, Brazil) composition kg-1: folic acid $1200 \mathrm{mg}$, antioxidant $5000 \mathrm{mg}$, biotin $200 \mathrm{mg}$, coline $100000 \mathrm{mg}$, cobalto $80 \mathrm{mg}$, copper $3500 \mathrm{mg}$, iron $20000 \mathrm{mg}$, iodine $160 \mathrm{mg}$, inositol $25000 \mathrm{mg}$, manganese $10000 \mathrm{mg}$, niacin $20000 \mathrm{mg}$, selenium $100 \mathrm{mg}$, vitamin (vit) A $2400000 \mathrm{UI}$, vit $B_{1} 4000 \mathrm{mg}$, vit $B_{2} 4000 \mathrm{mg}$, vit $B_{6} 3500$, vit $B_{12} 8000 \mathrm{mg}$, vit $B_{2} 4000 \mathrm{mg}$, vit $B_{5} 10000 \mathrm{mg}$, vit $B_{6} 3500 \mathrm{mg}$, vit C $60000 \mathrm{mg}$, vit $D_{3} 600000$ UI, vit E 30000 UI, vit K 3000 mg, zinc 24000 mg; ${ }^{6}$ Biolys e DL-Methionine (Evonik Degussa Brazil Ltda, São Paulo, Brazil); ${ }^{7}$ Nitrogen-free extract = $100-\left(\%\right.$ crude protein $+\%$ fat $+\%$ ash $+\%$ fiber); ${ }^{81}$ US $\$$ dollar $=3.25$ Brazilian reais

The practical ingredient values for digestible protein, essential amino acids, and energy already defined for jundiá were used to formulate the experiment diets (Freitas, 2015; Oliveira Filho and Fracalossi, 2006). The inclusion ratios of the major protein sources (soy protein concentrate and poultry by-product meal) varied from diet to diet (Table 1) whereas a fixed amount of salmon by-product meal was included in all diets to ensure a balance of essential amino acids, as well as an appropriate n-3: n-6 fatty acid ratio. The amount of soybean oil included in the experimental diets varied slightly 10.9 to $1.8 \%$ ) and the DP:DE ratios were maintained mainly by the inclusion of ground corn as a carbohydrate source following the approach used in previous jundiá studies (Gominho-Rosa et al., 2015).

The dry ingredients were ground to $1 \mathrm{~mm}$ particles in a hammer mill and screened through a $600 \mu \mathrm{m}$ mesh. A vitamin-mineral premix was combined with the fine dry ingredients and homogenized for $10 \mathrm{~min}$. Soybean oil was added to the resultant batter which was mixed for a further $10 \mathrm{~min}$. The moisture content of the mixture was adjusted to 20-25\% using a moisture-determining scale. The mixture was then extruded at $100{ }^{\circ} \mathrm{C}$ in a $3 \mathrm{~mm}$ matrix, and the resulting pellets were dried at $55{ }^{\circ} \mathrm{C}$ in a convection oven until the moisture content reached $10 \%$. The experimental feeds were stored at $-20{ }^{\circ} \mathrm{C}$ until used.

\section{Experiment conditions}

Approximately 600 jundiá juveniles (average weight
$31.54 \pm 4.92 \mathrm{~g}$ ) were acclimatized in $1000 \mathrm{~L}$ circular tanks for 10 days. Thereafter, the fish were anesthetized with clove oil and an alcohol solution (80 $\mathrm{mg} \mathrm{L}^{-1}$ ) diluted in water $\left(0.4 \mathrm{~mL} \mathrm{~L}^{-1}\right)$ and weighed individually. Groups of 25 individuals were randomly assigned to 15 experimental units (70 L tanks) providing five treatments with three replicates each. The tanks were connected to a closed water recirculation system, equipped with a biofilter, mechanical filter, continuous aeration, and temperature control. The mean water flow rate in each tank was $1 \mathrm{~L} \mathrm{~min}{ }^{-1}$ and the salinity of the water was maintained at a concentration of $2 \mathrm{~g} \mathrm{~L}^{-1}$ to prevent Ichthyophthiriasis (Baldisserotto et al., 2010). The photoperiod was $12 \mathrm{~h}$ light (07h00 to 19h00).

The 75-day feeding trial began after the fish had become acclimatized to the diets and management routines for two weeks. The experiment diets were offered daily at $09 \mathrm{~h} 00$ and $16 \mathrm{~h} 00$, and the fish were fed until apparent satiety. Daily feed intake per tank was recorded by calculating the difference in weight of food before the first and after the second feeding.

\section{Weight monitoring, determination of performance variables, and body composition sampling}

At two-week intervals, the fish in each tank were fasted for $24 \mathrm{~h}$, counted and weighed individually. The following variables were determined: (1) daily weight gain $(\mathrm{DWG}=$ (final weight - initial weight) $/$ days of experiment), (2) specific growth rate (SGR = (ln (final 
weight $)-\ln ($ initial weight) $) \times 100 /$ days of experiment , (3) feed conversion ratio (FCR = dry feed consumed / (wet final weight - wet initial weight)), and (4) daily dietary intake (DDI $=$ [dry matter consumption / /final weight + initial weight) / 2] / days of experiment $\times 100$ ).

At the start of the experiment, two samples of 20 fish were collected for determination of initial body composition and five fish per experiment unit (15 fish per treatment) were collected for analysis of final body composition after 75 days. Apparent net protein utilization (ANPU) was calculated as ANPU $=100 \times$ (final body protein $x$ final weight - initial body protein $x$ initial weight) / protein consumption in the dry matter. The remaining fish in each experiment unit $/ 60$ fish per treatment) were weighed individually, their viscera removed and weighed, and their livers separated and weighed to determine the viscerosomatic /VSI = /viscera weight / total animal weight $\times 100$ ) and hepatosomatic $(\mathrm{HSI}=$ (liver weight $/$ total animal weight $) \times 100)$ indexes, respectively. The fish were euthanized with an overdose of clove oil and alcohol solution. All fish were handled in accordance with the Ethics Committee on Animal Use of the Federal University of Santa Catarina, and fish management and sampling were approved according to protocol No. PP00815 CEUA/UFSC. Animal handling and stress were minimized during the study.

\section{Diet cost evaluation}

The costs of the experiment diets were determined based on the market price of the ingredients. The following indices were used for the economic evaluation of the five experiment diets: (1) average cost of feed $(\mathrm{ACF}=$ feed consumed $\times$ price of diet / gain in weight), (2) economic efficiency index $(\mathrm{EEI}=100 \times$ lowest $\mathrm{ACF}$ between diets / ACF of diet assessed), and (3) cost index (CI = 100 $\times$ ACF diet / lowest ACF between diets). These indices were proposed by Bellaver et al. (1985) and Barbosa et al. (1992).

\section{Diet and water analyses}

The experiment diets were analyzed following AOAC (2012) methodologies. Dry matter was determined by oven drying at $105{ }^{\circ} \mathrm{C}$ until constant weight (method 950.01) and mineral matter by incineration at $550{ }^{\circ} \mathrm{C}$ (method 942.05). Lipid content was determined by ether extraction using a Soxhlet extractor, after acid hydrolysis in the case of the feeds (method 920.39C), and crude protein by Kjeldahl $\mathrm{N} \times 6.25$ (method 945.01). The energy content was analyzed using a calorimeter following the method of Potter and Matterson (1960), and the fiber content by digestion in neutral detergent following the method proposed by Van Soest (1994). Fish body composition was analyzed following the same methodologies, except for the analysis of fiber and the acid hydrolysis prior to ether extraction which were not performed.
Daily monitoring of water quality indicators (temperature, dissolved oxygen, salinity, and $\mathrm{pH}$ ) was conducted after the $16 \mathrm{~h} 00$ feed using a multiparameter probe. Hardness, alkalinity, and nitrogen compounds (nitrite and total ammonia nitrogen) were measured every 15 days using a photocolorimeter. The mean temperature $\left(26.90 \pm 0.12{ }^{\circ} \mathrm{C}\right)$, dissolved oxygen, (6.40 $\left.\pm 0.08 \mathrm{mg} \mathrm{L}^{-1}\right)$, salinity $\left(1.90 \pm 0.03 \mathrm{~g} \mathrm{~L}^{-1}\right), \mathrm{pH}(6.80$ \pm 0.04), hardness (93.20 $\left.\pm 1.46 \mathrm{mg} \mathrm{L}^{-1} \mathrm{CaCO}_{3}\right)$, total alkalinity $(22.33 \pm 1.85 \mathrm{mg} \mathrm{L} \mathrm{CaCO})_{3}$, and ammonia $\left(0.21 \pm 0.02 \mathrm{mg} \mathrm{L}^{-1}\right)$ were within the optimal range for jundiá (Baldisserotto et al., 2010). The nitrite content remained close to zero throughout the feeding trial.

During the final week of the experiment, the concentration of total ammonia nitrogen (TAN) in each tank was measured at short intervals to determine the daily TAN curve for each treatment. For the TAN determination, the recirculating system was turned off during the sampling period; however, water aeration continued. Beginning one and a half hours after each feeding (09h00 and 16h00), water samples (500 mL) were collected from each of the 15 experimental units at half hour intervals for a total of $10 \mathrm{~h}$. The water samples ( $\mathrm{n}=300$ ) were immediately vacuum filtered / < $10 \mathrm{~mm} \mathrm{Hg})$ in a glass fiber filter $(1.2 \mu \mathrm{m})$ for subsequent colorimetric determination using a spectrophotometer following the methodology described by Valderrama (1981).

\section{Statistical analyses}

A one-way analysis of variance (ANOVA; $\alpha=0.05$ ) was used to detect differences between the treatments. All studied variables presented normality and homogeneity of variance. Polynomial regressions were plotted to determine the optimal levels for each variable. All statistical analyses were performed in RStudio.

\section{Results}

There was no fish mortality during the study and the different DP:DE dietary ratios affected most of the performance variables and cost indices (Table 2). Final weight, DWG, SGR, and DDI increased, while FCR improved with the DP:DE ratio increasing up to and including $27 \mathrm{~g} \mathrm{MJ}^{-1}$. The highest ANPU was supported by the diet containing $22 \mathrm{~g} \mathrm{MJ}^{-1} \mathrm{DP}: \mathrm{DE}$, and there was a reduction in ANPU values as the DP:DE ratio of the diets increased further. Regression analysis showed that the best daily weight gain was achieved with a ratio of $26.62 \mathrm{~g} \mathrm{MJ}^{-1} \mathrm{DP}: \mathrm{DE}$ in the $\operatorname{diet}$ (38.64\% DP and $\left.14.86 \mathrm{MJ} \mathrm{kg}^{-1} \mathrm{DE}\right)$. However, the highest ANPU corresponded with a lower DP:DE ratio of 23.72 $\mathrm{g} \mathrm{MJ}^{-1}$, which equates to a diet containing $32.23 \%$ DP and $13.46 \mathrm{MJ} \mathrm{kg}^{-1} \mathrm{DE}$ (Figure 1). The cost of the diets increased proportionally with the increase in DP and DE (Table 2) except for the $20 \mathrm{~g} \mathrm{MJ}^{-1} \mathrm{DP}: \mathrm{DE}$ diet, which was supplemented with synthetic amino acids. 
Table 2 - Effects of different digestible protein: digestible energy (DP:DE) ratios on performance and economic variables in culture of jundiá (Rhamdia quelen) juveniles for 75 days.

\begin{tabular}{|c|c|c|c|c|c|c|}
\hline \multirow{2}{*}{ Variables $^{1}$} & \multicolumn{5}{|c|}{$\begin{array}{c}\left.\text { Digestible protein (DP, } \mathrm{g} \mathrm{kg}^{-1}\right) \text { : Digestible energy (DE, } \mathrm{MJ} \mathrm{kg}^{-1} \text { ) } \\
\text { DP:DE ratio }\left(\mathrm{g} \mathrm{MJ}^{-1}\right)\end{array}$} & \multirow{2}{*}{$\begin{array}{l}\text { Best } \\
\text { DP:DE }\end{array}$} \\
\hline & 20 & 22 & 25 & 27 & 29 & \\
\hline Final weight ${ }^{2}(\mathrm{~g})$ & $53.55 \pm 2.61$ & $68.18 \pm 3.82$ & $71.48 \pm 0.71$ & $82.10 \pm 2.61$ & $73.66 \pm 1.91$ & 26.74 \\
\hline Daily weight gain ( $\mathrm{g} \mathrm{d}^{-1}$ ) & $0.29 \pm 0.02$ & $0.49 \pm 0.04$ & $0.55 \pm 0.01$ & $0.67 \pm 0.02$ & $0.56 \pm 0.02$ & 26.62 \\
\hline Specific growth rate $\left(\% \mathrm{~d}^{-1}\right)$ & $0.69 \pm 0.03$ & $1.02 \pm 0.05$ & $1.15 \pm 0.02$ & $1.26 \pm 0.01$ & $1.13 \pm 0.01$ & 26.39 \\
\hline Daily dietary intake (\% weight $\mathrm{d}^{-1}$ ) & $1.04 \pm 0.02$ & $1.16 \pm 0.04$ & $1.27 \pm 0.03$ & $1.39 \pm 0.02$ & $1.36 \pm 0.04$ & 29.57 \\
\hline Feed conversion ratio & $1.54 \pm 0.06$ & $1.20 \pm 0.02$ & $1.17 \pm 0.03$ & $1.18 \pm 0.02$ & $1.28 \pm 0.02$ & 25.38 \\
\hline Economic efficiency index (\%) & $66.84 \pm 2.51$ & $97.41 \pm 1.29$ & $90.77 \pm 2.59$ & $81.88 \pm 1.38$ & $69.72 \pm 2.69$ & 24.30 \\
\hline Cost index (\%) & $150.05 \pm 5.87$ & $102.69 \pm 1.35$ & $110.35 \pm 3.20$ & $122.20 \pm 2.05$ & $143.85 \pm 5.34$ & 24.39 \\
\hline
\end{tabular}

${ }^{1}$ Mean ( \pm standard error) of three replicates. The polynomial regression analysis was significant $(<0.001)$ for the variables, generating the following equations: final weight: $y=-0.52 x^{2}+27.68 x-292.41\left(R^{2}=0.77\right)$; daily weight gain: $y=-0.01 x^{2}+0.39 x-4.63\left(R^{2}=0.86\right) ;$ specific growth rate: $y=-0.01 x^{2}+0.68 x-7.69$ $\left(R^{2}=0.93\right) ;$ daily dietary intake: $y=-0.004 x^{2}+0.221 x-1.891\left(R^{2}=0.87\right)$; feed conversion ratio: $y=0.01 x^{2}-065 x+9.36\left(R^{2}=0.76\right)$; economic efficiency index: $y=-1.28 x^{2}+62.31 x-661.84\left(R^{2}=0.75\right)$; cost index: $y=2.07 x^{2}-101.14 x+1337.13\left(R^{2}=0.77\right)$. Initial weight: $31.54 \pm 4.92 \mathrm{~g}$.

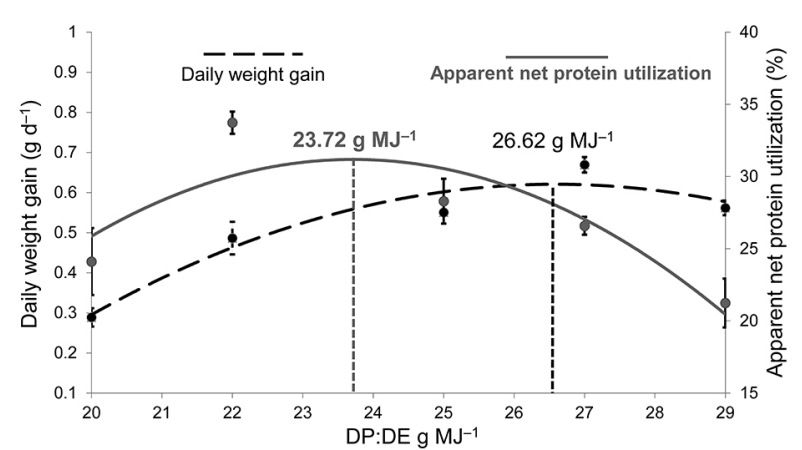

Figure 1 - Apparent net protein utilization $\left(y=-0.38 x^{2}+18.24 x\right.$ $\left.-185.17 ; R^{2}=0.59 ; p<0.0001\right)$ and daily weight gain $(y=$ $\left.-0.01 x^{2}+0.39 x-4.63 ; R^{2}=0.86 ; p<0.0001\right)$ in jundiá (Rhamdia quelen) juveniles fed diets containing different digestible protein: digestible energy (DP:DE) ratios for 75 days.

These findings indicate that diet cost, weight gain, and FCR significantly influenced the other economic indices. The best FCR was estimated for fish fed a diet with a DP:DE ratio of $25.38 \mathrm{~g} \mathrm{MJ}^{-1}(36.08 \% \mathrm{DP}$ and $14.03 \mathrm{MJ} \mathrm{kg}^{-1} \mathrm{DE}$ ), whereas the lowest ACF was for a diet with a DP:DE ratio of $24.39 \mathrm{~g} \mathrm{MJ}^{-1}$ (33.83 \% DP and $13.65 \mathrm{MJ} \mathrm{kg}^{-1}$ ) (Figure 2).

Moisture content, ash, crude protein, and the VSI were not altered by variation in the DP:DE ratio of the diets (Table 3), whereas body fat and HSI were significantly affected. An increase in fat content and a decrease in the HSI of jundiá was observed in response to the increasing DP:DE ratio in the diets (Figure 3).

Total ammonia nitrogen concentration, monitored during the last week of the feeding trial, increased linearly with an increase in protein concentration associated with the increase in DP:DE ratio (Figure 4). The highest value $\left(0.49 \mathrm{mg} \mathrm{TAN} \mathrm{kg}^{-1}\right)$ was obtained when fish were fed the $29 \mathrm{~g} \mathrm{MJ}^{-1} \mathrm{DP}: \mathrm{DE}$ diet. The mean excretion of ammonia was estimated at 0.32 and $0.35 \mathrm{mg}^{\mathrm{TAN} \mathrm{kg}} \mathrm{k}^{-1}$ body weight for fish fed diets containing DP:DE ratios of 23.72 and $24.39 \mathrm{~g}$ $\mathrm{MJ}^{-1}$, respectively.

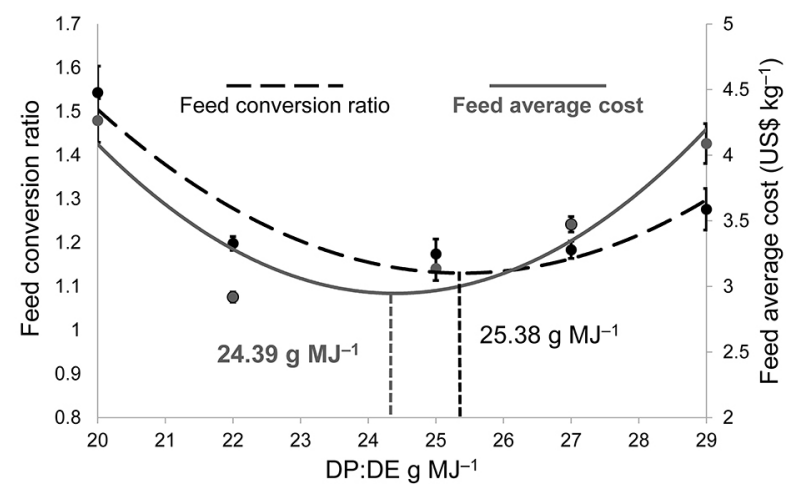

Figure 2 - Average feed cost $\left(y=0.06 x^{2}-2.88 x+38.05 ; R^{2}=\right.$ $0.77 ; p<0.0001)$ and feed conversion ratio $\left(y=0.01 x^{2}-065 x+\right.$ 9.36; $\mathrm{R}^{2}=0.76 ; p<0.0001$ ) in jundiá (Rhamdia quelen) juveniles fed diets containing different digestible protein: digestible energy (DP:DE) ratios for 75 days.

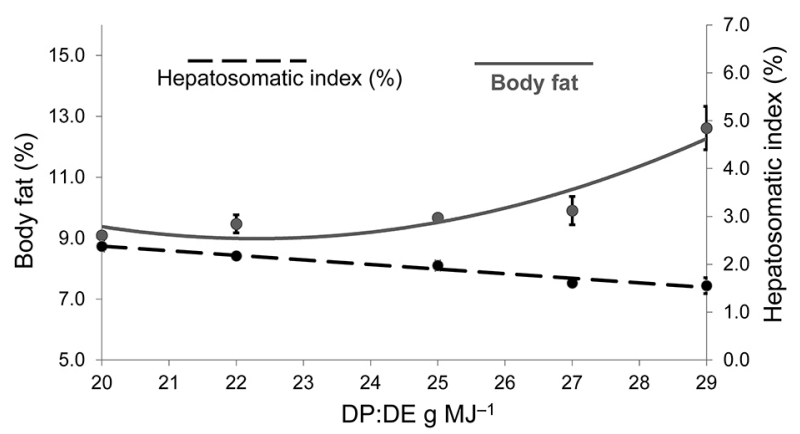

Figure 3 - Body fat $\left(y=0.07 x^{2}-3.27 x+45.47 ; R^{2}=0.73\right.$; $p<0.05)$ and hepatosomatic index $\left(y=-0.1 x+4.3 ; R^{2}=\right.$ $0.81 ; p<0.0001$ ) in jundiá (Rhamdia quelen) juveniles fed diets containing different digestible protein: digestible energy (DP:DE) ratios for 75 days.

\section{Discussion}

Most variables evaluated in this study reflect that jundia responded to variations in the DP:DE ratio of 
Table 3 - Body composition (wet matter basis) and viscerosomatic index of jundiá (Rhamdia quelen) juveniles ${ }^{1}$ fed diets containing different digestible protein: digestible energy (DP:DE) ratios for 75 days.

\begin{tabular}{|c|c|c|c|c|c|c|}
\hline \multirow{2}{*}{$\begin{array}{l}\text { Variable }{ }^{2} \\
(\%)\end{array}$} & \multicolumn{5}{|c|}{$\begin{array}{c}\text { Digestible protein (DP, } \mathrm{g} \mathrm{kg}^{-1} \text { ): Digestible energ (DE, } \mathrm{MJ} \mathrm{kg}^{-1} \text { ) } \\
\text { DP:DE ratio (g MJ-1) }\end{array}$} & \multirow{2}{*}{$\begin{array}{c}p \\
\text { value }\end{array}$} \\
\hline & 20 & 22 & 25 & 27 & 29 & \\
\hline Moisture & $70.97 \pm 0.16$ & $70.49 \pm 0.12$ & $69.76 \pm 0.36$ & $70.23 \pm 0.36$ & $69.18 \pm 2.02$ & 0.9886 \\
\hline Crude protein & $14.40 \pm 0.16$ & $15.28 \pm 0.03$ & $14.60 \pm 0.23$ & $15.18 \pm 0.20$ & $15.03 \pm 0.30$ & 0.3162 \\
\hline Ash & $5.97 \pm 0.05$ & $5.49 \pm 0.05$ & $6.31 \pm 0.56$ & $5.42 \pm 0.03$ & $4.80 \pm 0.03$ & 0.0629 \\
\hline Viscerosomatic index & $8.55 \pm 0.12$ & $8.84 \pm 0.19$ & $8.43 \pm 0.08$ & $8.84 \pm 0.24$ & $8.78 \pm 0.36$ & 0.8701 \\
\hline
\end{tabular}

${ }^{1}$ Initial weight: $31.54 \pm 4.92 \mathrm{~g}$. ${ }^{2}$ Mean ( \pm standard error) of three replicates. The polynomial regression analyses were not significant $(p>0.05)$.

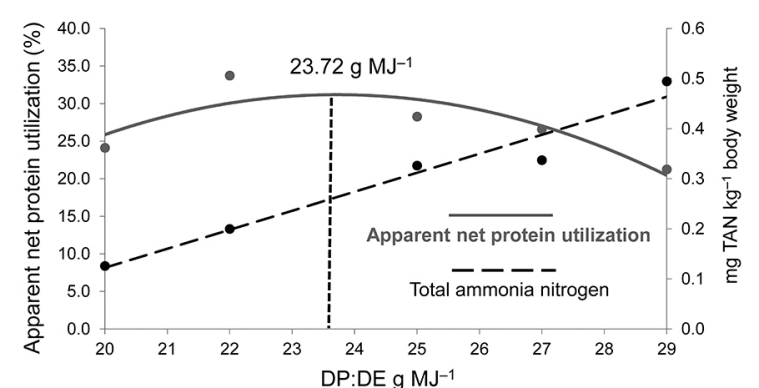

Figure 4 - Apparent net protein utilization $\left(y=-0.38 x^{2}+18.24 x\right.$ $-185.17 ; R^{2}=0.59 ; p<0.0001$ ) and the concentration of total ammonia nitrogen (TAN) in the water $\left(y=-0.04 x-063 ; R^{2}=\right.$ $0.86 ; p<0.0001$ ) of tanks stocked with jundiá (Rhamdia quelen) juveniles fed diets containing different digestible protein: digestible energy (DP:DE) ratios for 75 days.

the experiment diets. The best fish performance results were obtained for diets with DP:DE ratios between 22 and $27 \mathrm{~g} \mathrm{MJ}^{-1}$, corresponding to a range of 29 to $39 \% \mathrm{DP}$ and 13.39 to $14.64 \mathrm{MJ} \mathrm{kg}^{-1} \mathrm{DE}$, respectively.

Fish fed diets containing the extreme DP:DE ratios (20 and $29 \mathrm{~g} \mathrm{MJ}^{-1}$ ) showed lower weight gain and ANPU than those which were fed the other diets. Fish that were fed the diet with $29 \mathrm{~g} \mathrm{MJ}^{-1} \mathrm{DP}: \mathrm{DE}$ exhibited the highest excretion of ammonia and the highest accumulation of body fat in comparison to fish that were fed the other diets. These findings suggest that the protein level of this diet is above that required by this species and is unbalanced in relation to the energy content. Under these circumstances, it is likely that amino acids are catabolized to meet energy needs, with a consequent reduction in growth rate, and surplus protein is stored as body fat which, in addition, could also be excreted in the form of nitrogen (Mock et al., 2019; NRC, 2011; Steffens, 1989).

Studies where jundiá was fed diets containing increasing protein levels and decreasing nitrogen-free extract (NFE, an indicator of the digestible carbohydrate content in the diet) have reported increased activity of digestive and liver enzymes related to amino acid and carbohydrate metabolism, as well as increased concentrations of free amino acids, ammonia, and urea in the plasma and liver (Melo et al., 2006; Melo et al., 2012; Melo et al., 2016). Such metabolic responses could be related to the use of dietary protein as an energy source because of the excess of this nutrient, and the DP:DE ratio imbalance, both of which could explain the results observed in this study for fish fed the $29 \mathrm{~g} \mathrm{MJ}^{-1} \mathrm{DP}: \mathrm{DE}$ ratio diet. This diet had the highest protein and energy levels of those evaluated and contained only a small amount of corn (13.4\%), resulting in an NFE of only 7.49 $\%$. This relatively low availability of a non-protein energy source, coupled with the high protein concentration of this diet, may have favored the use of protein as an energy supply to the detriment of protein synthesis, resulting in a relatively small increase in growth.

The diet with the lowest DP:DE ratio $(20 \mathrm{~g}$ $\mathrm{MJ}^{-1}$ ), which contained the highest corn inclusion (58.9\%), affected fish growth negatively. Fish fed this diet showed the lowest values for all the performance variables evaluated. Studies report that jundiá is not a typical omnivore and has a low tolerance to dietary carbohydrates (Gominho-Rosa et al., 2015; Moro et al., 2010; Oliveira Filho and Fracalossi, 2006; Rodrigues et al., 2012). The NFE (32.73 \%) in the diet with a $20 \mathrm{~g} \mathrm{MJ}^{-1}$ DP:DE ratio is close to the tolerance limit reported for this species where the inclusion of $30 \%$ cornstarch in the diet (about $37 \% \mathrm{NFE}$ ) promoted the accumulation of free fatty acids and triacylglycerols in the liver of these fish (mean weight $24 \mathrm{~g}$ ), promoting high HSI values and hepatic steatosis. It has also been reported that diets rich in NFE favor the accumulation of hepatic glycogen in jundiá (Moro et al., 2010). Although these metabolic intermediates were not evaluated in the present study, fish fed the $20 \mathrm{~g} \mathrm{MJ}^{-1}$ DP:DE ratio diet exhibited the highest HSI values, suggesting that the effects reported in these previous studies may also have occurred in jundiá fed this diet.

The likely negative effects of excess non-protein energy seemed to impair the consumption and weight gain of fish fed the $20 \mathrm{~g} \mathrm{MJ}^{-1} \mathrm{DP}$ :DE ratio diet. It is known that voluntary feed intake is essentially regulated by digestible energy in relation to the amount of protein in the diet (NRC, 2011) and this was observed in the present study. The diet with the lowest DP:DE ratio resulted in a considerably low DDI than the other diets. This, coupled with low protein retention, suggests that there may have been an interruption in feed intake even before the fish had consumed sufficient protein to meet the minimum requirement for this species. Similar 
results were reported for small-sized jundiá (mean weight $1.52 \mathrm{~g}$ to $10.96 \mathrm{~g}$ ) by Meyer and Fracalossi (2004), when fed diets rich in non-protein energy (excess carbohydrates).

The nutrient requirements of a species are determined by the minimum concentrations needed in the diet to provide maximum growth (Jobling, 2016; Lovell, 1998). In general, studies consider the optimal dietary P:E ratio as that which provides maximum weight gain, since this variable is usually the most suitable for estimating nutritional requirements in fish (Cowey, 1992). In the present study, the best DP:DE ratio estimate, based on weight gain, corresponded to $26.62 \mathrm{~g} \mathrm{MJ}^{-1}$ (38.64\% DP and $\left.14.86 \mathrm{MJ} \mathrm{kg}^{-1} \mathrm{DE}\right)$. However, weight gain does not always accurately reflect how consumed nutrients and energy are used for growth. This is likely to be the case for the 27 and 29 $\mathrm{g} \mathrm{MJ}^{-1} \mathrm{DP}: \mathrm{DE}$ diets which, in comparison to the other diets, resulted in higher weight gain in the fish but sub-optimal ANPU and body fat values, suggesting less efficiency in the use of the feed consumed. To avoid any erroneous interpretation of the optimal DP:DE ratio, variables that express weight gain based on feed intake, such as the FCR should be used (Glencross et al., 2007; Jobling, 2001).

In the present study, the best FCR was estimated for a diet with a DP:DE ratio of $25.38 \mathrm{~g} \mathrm{MJ}^{-1}$ (36.08\% DP and $14.03 \mathrm{MJ} \mathrm{kg}^{-1} \mathrm{DE}$ ). However, the FCR is calculated based on feed consumption which is difficult to measure accurately in the aquatic environment. In addition, the FCR is based on total feed intake which hampers the specific estimation of how energy and/or some of the dietary nutrients have been utilized by the fish. This is illustrated by the results obtained for the 25 and $27 \mathrm{~g}$ $\mathrm{MJ}^{-1} \mathrm{DP}$ :DE ratio diets, where the fish presented different feed intakes, but similar FCRs and significantly different ANPU and body fat deposition. One way to circumvent this is to estimate the best dietary DP:DE ratio from variables that reconcile weight gain and changes in fish body composition such as ANPU (Lupatsch, 2009).

The results showed that the best ANPU in jundiá juveniles would potentially be achieved with a DP:DE ratio of $23.72 \mathrm{~g} \mathrm{MJ}^{-1}$, representing a diet of $32.23 \%$ $\mathrm{DP}$ and $13.46 \mathrm{MJ} \mathrm{kg}^{-1} \mathrm{DE}$. The experimental diets with protein and energy levels close to this ratio (22 and 25 $\mathrm{g} \mathrm{MJ}^{-1}$ ) did not produce the greatest fish weight gain; however, they yielded better ANPU and FCR values, as well as lower accumulation of body fat. Lower body fat accumulation is significant because it directly influences the quality and shelf life of fish. Reduced fat content is related to lower rates of lipid oxidation, a major cause of fish decay (Davis et al., 1999; Sant'Ana et al., 2011). In addition, it was noted that better ANPU promoted by a favorable dietary DP:DE ratio resulted in the excretion of intermediate levels of TAN, as has been demonstrated in other studies (Debnath et al., 2012; Engin and Carter, 2001; Green and Hardy, 2008; McGoogan and Gatlin, 1999, 2000; Ozorio et al., 2001). Ammonia is the main nitrogen product of protein metabolism in fish having a deleterious effect on water quality. The inclusion of adequate DE favors greater protein utilization and, consequently, lower nitrogen excretion (Mock et al., 2019).

Along with the aforementioned aspects, a definition of the best DP:DE ratio for jundiá juveniles should also consider the minimum cost of production by relating growth indices to economic variables (Lupatsch, 2009). Since the cost of feed accounts for a large proportion of the operational costs of an aquaculture enterprise, it is necessary to ensure, through the maintenance of an optimal DP:DE ratio, that dietary protein, which is relatively costlier, is utilized for growth, while lower cost carbohydrates and lipids are metabolized for energy supply (Lovell, 1998; Mock et al. 2019; Silva et al., 2020).

In the present study, it was estimated that the lowest AFC would be achieved with a DP:DE ratio diet of $24.39 \mathrm{~g} \mathrm{MJ}^{-1}$ (33.83\% DP and $\left.13.65 \mathrm{MJ} \mathrm{kg}^{-1}\right)$. Cost indices, calculated for each experimental diet, were influenced by weight gain, FCR, and diet costs per se. The $20 \mathrm{~g} \mathrm{MJ}^{-1} \mathrm{DP}: \mathrm{DE}$ ratio diet yielded the highest ACF and CI and lowest EEI values. Although this diet had a lower protein content, the inclusion of synthetic amino acids resulted in a higher cost compared to the diet with a $22 \mathrm{~g} \mathrm{MJ}^{-1} \mathrm{DP}: \mathrm{DE}$.

Despite providing high weight gain, the diet with $29 \mathrm{~g} \mathrm{MJ}^{-1} \mathrm{DP}: \mathrm{DE}$ did not show economic potential, mainly because of its high protein content and worse FCR. In contrast, the diets with DP:DE ratios of 22 and $25 \mathrm{~g} \mathrm{MJ}^{-1}$ showed the best indices of economic efficiency. Although yielding the second lowest weight gain compared to other experimental diets, the low cost of the $22 \mathrm{~g} \mathrm{MJ}^{-1} \mathrm{DP}: \mathrm{DE}$ diet provided the best ACF, EEI, and $\mathrm{CI}$ values. The diet with $25 \mathrm{~g} \mathrm{MJ}^{-1} \mathrm{DP}: \mathrm{DE}$, the ratio closest to those estimated for optimal ANPU and lower $\mathrm{ACF}$, showed the best FCR and an intermediate ACF compared to that of the other treatment diets.

For successful farming of jundiá, it is necessary to determine the optimal dietary DP:DE ratios for other life stages since the present study focused only on the initial grow-out phase ( 30 to $80 \mathrm{~g}$ average weight). This need is related to dietary requirement changes during different developmental stages as well as to the reduction in utilization capacity of some nutrients as the fish grow (NRC, 2011).

\section{Conclusions}

The estimated dietary DP:DE ratios for optimal ANPU and economic performance were $23.72 \mathrm{~g} \mathrm{MJ}^{-1}$ (32.23\% DP and $13.46 \mathrm{MJ} \mathrm{kg}^{-1} \mathrm{DE}$ ) and $24.39 \mathrm{~g} \mathrm{MJ}^{-1}$ (33.83\% $\mathrm{DP}$ and $13.65 \mathrm{MJ} \mathrm{kg}^{-1}$, respectively. However, for an economically viable and environmentally friendly culture, it is necessary to balance the variables. Therefore, $25 \mathrm{~g}$ $\mathrm{MJ}^{-1} \mathrm{DP}: \mathrm{DE}$ (34.05\% DP and $13.81 \mathrm{MJ} \mathrm{kg}^{-1}$ ) is proposed as the optimal DP:DE ratio for jundiá juveniles in the initial grow-out stage (30 to $80 \mathrm{~g}$ average weight). 


\section{Acknowledgments}

The authors acknowledge financial support from the Foundation for Research and Innovation Support of the Santa Catarina State (FAPESC, SC \#2012000298), as well as the fellowships granted by the Coordination of Improvement of Higher Education Personnel (CAPES) and National Council for Scientific and Technological Development $(\mathrm{CNPq})$ for the first and third authors, respectively. We also thank the Agricultural Research and Rural Extension (EPAGRI) for donating the fish used in the study, and the companies Evonik, In vivo, Tectron, Nicoluzzi, and IMCOPA for the donation of some of the ingredients used in the manufacture of the experimental diets.

\section{Authors' Contributions}

Conceptualization: Freitas, L.E.L.; Fracalossi, D.M. Data acquisition: Freitas, L.E.L. Data analysis: Freitas, L.E.L.; Silva, T.S.C. Design of methodology: Freitas, L.E.L.; Fracalossi, D.M. Writing and editing: Freitas, L.E.L.; Fracalossi, D.M.; Silva, T.S.C.

\section{References}

Association of Official Agricultural Chemists - International [AOAC]. 2012. Official Methods of Analysis. 19ed. AOAC, Washington, DC, USA.

Baldisserotto, B.; Randüz Neto, J.; Barcellos, L.G. 2010. Jundiá (Rhamdia sp.). p. 301-333. In: Baldisserotto, B.; Gomes, L.C., eds. Native species for fish farming in Brazil = Espécies nativas para piscicultura no Brasil. 2ed. EDUSFM, Santa Maria, RS, Brazil (in Portuguese).

Barbosa, H.P.; Fialho, E.T.; Ferreira, A.S.; De Lima, G.J.M.M.; Maciel Gomes, M.F. 1992. Wheat middlings for weaning, growing and finishing pigs. Revista Brasileira de Zootecnia 21: 827-837 (in Portuguese, with abstract in English).

Bellaver, C.; Fialho, E.T.; Protas, J.F.D.S.; Gomes, P.C. 1985. Malt rootlets as ration ingredients for swine on growing and finishing stages. Pesquisa Agropecuária Brasileira 20: 969-974 (in Portuguese, with abstract in English).

Cowey, C.B. 1992. Nutrition: estimating requirements of rainbow trout. Aquaculture 100: 177-189. https://doi. org/10.1016/0044-8486(92)90370-Z

Davis, D.A.; Lazo, J.P.; Arnold, C.R. 1999. Response of juvenile red drum (Sciaenops ocellatus) to practical diets supplemented with medium chain triglycerides. Fish Physiology and Biochemistry 21: 235-248. https://doi. org/10.1023/A:1007836612376

Debnath, D.; Pal, A.K.; Sahu, N.P.; Yengkokpam, S.; Baruah, K. 2012. Protein requirement of Labeo rohita fingerlings based on growth and ammonia excretion. Journal of the Inland Fisheries Society of India 44: 12-20.

Engin, K.; Carter, C.G. 2001. Ammonia and urea excretion rates of juvenile Australian short-finned eel (Anguilla australis australis) as influenced by dietary protein level. Aquaculture 194: 123-136. https://doi.org/10.1016/S0044-8486(00)00506-8
Freitas, L.E.L. 2015. Energy: protein ratio in practical diets for jundiá juveniles (Rhamdia quelen): digestibility and growth performance. Doctoral Thesis (Aquicultura) - Universidade Federal de Santa Catarina, Florianópolis, SC, Brazil. 97p. (in Portuguese, with abstract in English). Available at: https://repositorio.ufsc.br/xmlui/ handle/123456789/169655

Glencross, B.D.; Booth, M.; Allan, G.L. 2007. A feed is only as good as its ingredients? A review of ingredient evaluation strategies for aquaculture feeds. Aquaculture Nutrition 13: 17-34. https://doi. org/10.1016/S0044-8486/00)00506-8

Gominho-Rosa, M.C.; Rodrigues, A.P.O.; Mattioni, B.; De Francisco, A.; Moraes, G.; Fracalossi, D.M. 2015. Comparison between the omnivorous jundiá catfish (Rhamdia quelen) and Nile tilapia (Oreochromis niloticus) on the utilization of dietary starch sources: digestibility, enzyme activity and starch microstructure. Aquaculture 435: 92-99. https://doi.org/10.1016/j. aquaculture.2014.09.035

Green, J.A.; Hardy, R.W. 2008. The effects of dietary protein: energy ratio and amino acid pattern on nitrogen utilization and excretion of rainbow trout Oncorhynchus mykiss (Walbaum). Journal of Fish Biology 73: 663-682. https://doi.org/10.1111/j.10958649.2008.01965.x

Guy, E.L.; Li, M.H.; Allen, P.J. 2018. Effects of dietary protein levels on growth and body composition of juvenile (age-1) Black Buffalo Ictiobus Niger. Aquaculture 492: 67-72.

Jobling, M. 2001. Feed composition and analysis. p. 1-24. In: Houlihan, D.; Boujard, T.; Jobling, M., eds. Food intake in fish. Blackwell Science, Oxford, UK. https://doi.org/10.1002/9780470999516.ch1

Jobling, M. 2016. Fish nutrition research: past, present and future. Aquaculture International 24: 767-786. https://doi.org/10.1007/ s10499-014-9875-2

Lovell, R.T. 1998. Nutrition and Feeding of Fish. Kluwer Academic, MA, USA.

Lupatsch, I. 2009. Quantifying nutritional requirements in aquaculture: the factorial approach. p. 417-439. In: Burnell, G.; Allan, G., eds. New technologies in aquaculture: improving production efficiency, quality and environmental management. Woodhead Publishing, Cambridge, UK.

McGoogan, B.B.; Gatlin, D.M. 1999. Dietary manipulations affecting growth and nitrogenous waste production of red drum, Sciaenops ocellatus I. Effects of dietary protein and energy levels. Aquaculture 178: 333-348. https://doi.org/10.1016/S00448486(99)00137-4

McGoogan, B.B.; Gatlin, D.M. 2000. Dietary manipulations affecting growth and nitrogenous waste production of red drum, Sciaenops ocellatus. II. Effects of energy level and nutrient density at various feeding rates. Aquaculture 182: 271-285. https://doi.org/10.1016/ S0044-8486(99)00260-4

Melo, J.F.B.; Lundstedt, L.M.; Inoue, L.A.K.; Metón, I.; Baanante, I. V.; Moraes, G. 2016. Glycolysis and gluconeogenesis in the liver of catfish fed with different concentrations of proteins, lipids and carbohydrates. Arquivo Brasileiro de Medicina Veterinária e Zootecnia 68: 1251-1258. http://dx.doi.org/10.1590/1678-4162-8337

Melo, J.F.B.; Lundstedt, L.M.; Metón, I.; Baanante, I. V.; Moraes, G. 2006. Effects of dietary levels of protein on nitrogenous metabolism of Rhamdia quelen (Teleostei: Pimelodidae). Comparative Biochemistry and Physiology Part A: Molecular and Integrative Physiology 145: 181-187. https://doi:10.1016/j.cbpa.2006.06.007 
Melo, J.F.B.; Lundstedt, L.M.; Moraes, G.; Inoue, L.A.K.A. 2012. Effect of different concentrations of protein on the digestive system of juvenile silver catfish. Arquivo Brasileiro de Medicina Veterinária e Zootecnia 64: 450-457. http://dx.doi. org/10.1590/S0102-09352012000200027

Meyer, G.; Fracalossi, D.M. 2004. Protein requirement of jundia fingerlings, Rhamdia quelen, at two dietary energy concentrations. Aquaculture 240: 331-343. https://doi. org/10.1016/j.aquaculture.2004.01.034

Mo, A.J.; Sun, J.X.; Wang, Y.H.; Yang, K.; Yang, H.S.; Yuan, Y.C. 2019. Apparent digestibility of protein, energy and amino acids in nine protein sources at two content levels for mandarin fish, Siniperca chuatsi. Aquaculture 499: 42-50.

Mock, T.S.; Francis, D.S.; Jago, M.K.; Glencross, B.D.; Smullen, R.P.; Keast, R.S.J.; Turchini, G.M. 2019. The impact of dietary protein: lipid ratio on growth performance, fatty acid metabolism, product quality and waste output in Atlantic salmon (Salmo salar). Aquaculture 501: 191-201.

Montes-Girao, P.J.; Fracalossi, D.M. 2006. Dietary lysine requirement as basis to estimate the essential dietary amino acid profile for Jundiá, Rhamdia quelen. Journal of the World Aquaculture Society 37: 388-396. https://doi.org/10.1111/ j.1749-7345.2006.00052.x

Moro, G.V.; Camilo, R.Y.; Moraes, G.; Fracalossi, D.M. 2010. Dietary non-protein energy sources: growth, digestive enzyme activities and nutrient utilization by the catfish jundiá, Rhamdia quelen. Aquaculture Research 41: 394-400. https://doi:10.1111/ j.1365-2109.2009.02352.x

National Research Council [NRC]. 2011. Nutrient Requirements of Fish and Shrimp. The National Academies Press, Washington, DC, USA. https://doi.org/10.17226/13039

Oliveira Filho, P.R.C.; Fracalossi, D.M. 2006. Apparent digestibility coefficients of feed ingredients for jundia juveniles. Revista Brasileira de Zootecnia 35: 1581-1587 (in Portuguese, with abstract in English). https://doi.org/10.1590/ S1516-35982006000600002

Ozorio, R.O.A.; van Eekeren, T.H.B.; Huisman, E.A.; Verreth, J.A.J. 2001. Effects of dietary carnitine and protein energy: nonprotein energy ratios on growth, ammonia excretion and respiratory quotient in African catfish, Clarias gariepinus (Burchell) juveniles. Aquaculture Research 32 Issue Supplement: 406-414. https://doi.org/10.1046/j.1355557x.2001.00031.x

Piedras, S.R.N.; Pouey, J.L.O.F.; Moraes, P.R.R.; Rodrigues, F.V. 2006. Response of silver catfish (Rhamdia sp.) fingerlings fed diets containing different levels of crude protein and digestible energy. Revista Brasileira de Agrociência 12: 217-220 (in Portuguese, with abstract in English). https://doi.org/10.18539/ cast.v12i2.4536
Potter, L.M.; Matterson, L.D. 1960. Metabolizable energy of feed ingredients for the growing chick. Poultry Science 39: 781-782. https://doi.org/10.3382/ps.0390781

Reidel, A.; Romagosa, E.; Feiden, A.; Boscolo, W.R.; Coldebella, A.; Signor, A.A. 2010. Catfish (jundia) body yield and chemical composition fed different protein and energy level in the diet, reared in net-tanks. Revista Brasileira de Zootecnia 39: 233-240 (in Portuguese, with abstract in English). https://doi. org/10.1590/S1516-35982010000200001

Rodrigues, A.P.O.; Gominho-Rosa, M.C.; Cargnin-Ferreira, E.; De Francisco, A.; Fracalossi, D.M. 2012. Different utilization of plant sources by the omnivorous jundiá catfish (Rhamdia quelen) and Nile tilapia (Oreochromis niloticus). Aquaculture Nutrition 18: 65-72. https://doi.org/10.1111/j.1365-2095.2011.00877.x

Salhi, M.; Bessonart, M.; Chediak, G.; Bellagamba, M.; Carnevia, D. 2004. Growth, feed utilization and body composition of black catfish, Rhamdia quelen, fry fed diets containing different protein and energy levels. Aquaculture 231: 435-444. https:// doi.org/10.1016/j.aquaculture.2003.08.006

Sant'Ana, L.S.; Soares, S.; Vaz-Pires, P. 2011. Development of a quality index method (QIM) sensory scheme and study of shelf-life of ice-stored blackspot seabream (Pagellus bogaraveo). Food Science and Technology 44: 2253-2259. https://doi. org/10.1016/j.lwt.2011.07.004

Signor, A.; Signor, A.A.; Feiden, A.; Boscolo, W.R.; Reidel, A.; Hayashi, C. 2004. Crude protein requirement for silver catfish (Rhamdia quelen) fingerlings. Revista Varia Scientia 4: 79-89 (in Portuguese, with abstract in English).

Silva, T.S.C.; Zanon, R.B.Z.; Mourão, G.B.; Cyrino, J.E.P. 2020. Digestible energy, protein, and energy-protein ratio requirements of Pseudoplatystoma reticulatum. Journal of the World Aquaculture Society. https://doi.org/10.1111/jwas.12701

Steffens, W. 1989. Principles of Fish Nutrition. Halsted Press, New York, NY, USA.

Tessaro, L.; Toledo, C.P.R.; Neumann, G.; Krause, R.A.; Meurer, F.; Natali, M.R.M.; Bombardelli, R.A. 2012. Growth and reproductive characteristics of Rhamdia quelen males fed on different digestible energy levels in the reproductive phase. Aquaculture 326-329: 74-80. https://doi.org/10.1016/j. aquaculture.2011.11.012

Valderrama, J.C. 1981. The simultaneous analysis of total nitrogen and total phosphorus in natural waters. Marine Chemistry 10: 109-122. https://doi.org/10.1016/0304-4203/81)90027-X

Van Soest, P.J. 1994. Nutritional Ecology of the Ruminant. Cornell University Press, New York, NY, USA. 